\title{
Effect of a fall cut on dry matter yield, nutritive value, and stand persistence of alfalfa
}

\author{
Iryna McDonald, Doohong Min and Rudra Baral ${ }^{*}$ \\ Department of Agronomy, Kansa State University, Manhattan, KS 66506, USA
}

Received: Feb 9, 2021

Revised: Mar 22, 2021

Accepted: Apr 14, 2021

*Corresponding author

Rudra Baral

Department of Agronomy, Kansa State University, Manhattan, KS 66506, USA.

Tel: +1-785-532-2292

E-mail: rudrabaral@ksu.edu

Copyright $\odot 2021$ Korean Society of Animal Sciences and Technology.

This is an Open Access article distributed under the terms of the Creative Commons Attribution

Non-Commercial License (http:// creativecommons.org/licenses/by$\mathrm{nc} / 4.0 /$ ) which permits unrestricted non-commercial use, distribution, and reproduction in any medium, provided the original work is properly cited.

ORCID

Iryna McDonald

https://orcid.org/0000-0002-4515-3305

Doohong Min

https://orcid.org/0000-0002-9404-5175

Rudra Baral

https://orcid.org/0000-0002-9018-9470

Competing interests

No potential conflict of interest relevant

to this article was reported.

Funding sources

This research was funded by the Department of Agronomy, Kansas

State University.

Acknowledgements

Not applicable.

Availability of data and material Upon reasonable request, the datasets of this study can be available from the corresponding author.

\begin{abstract}
Information is lacking about the effect of date of a fall cut of alfalfa (Medicago sativa L.) on dry matter yield (DMY), forage nutritive value, and stands persistence. The objective of this study was to determine the effect of timing of a fall cut on DMY, forage nutritive value and stand persistence of three alfalfa varieties: low-lignin Hi-Gest 360, Roundup Ready Tonica, and conventional Gunner in Northeastern Kansas in the United States. The field study was carried out by splitting plot in randomized complete block design with four replications. The harvesting data of different maturity stages were collected in each year from 2015 to 2018 . Three cuts were harvested based on the stage of maturity, and the last (fourth) cut was done on September 15, September 30, October 15, and October 30 of each year. The persistence of the alfalfa stands was determined each fall after the last cut, and each spring after the first cut, by counting the number of live plants in a randomly placed quadrat in each plot. Alfalfa cut on September 15 and September 30 had a higher stand persistence compared to alfalfa cut on October 15 and October 30. The DMY of the first cut in 2016 was significantly higher in roundup ready than the low-lignin alfalfa variety. In the second cut, DMY was significantly higher in conventional alfalfa than the roundup ready. There were no significant differences in DMY between alfalfa varieties in the rest of seasonal cuttings in 2016 and 2017 and annual total yield in both years. In general, low lignin alfalfa variety had higher crude protein and relative feed value and lower acid detergent fiber and neutral detergent fiber contents than those in roundup ready and conventional alfalfa varieties. On average, nutritive value of alfalfa was generally affected by last cutting dates in 2017. Based on 3-year data the last cutting of alfalfa in the fall could be done by September 30-October 15 without harmful effect on DMY.
\end{abstract} Keywords: Medicago sativa L., Fall cut, Dry matter yield, Nutritive value, Stand persistence

\section{INTRODUCTION}

Alfalfa is known as the "Queen of the Forages". It has the highest yield potential of any perennial forage legume adapted to the United States [1]. Also, it is highly advantageous to use it for feed for ruminants [2]. Changes in climatic conditions have extended warm or cold periods and often tempt a producer to cut alfalfa during the resting period, which is $4-6$ weeks before the first killing frost. But doing this initiates regrowth and reduces root reserves during a critical time [3]. Recommendations concerning the length of the fall resting period in alfalfa production are still under question. The date of the last cut 
Authors' contributions

Conceptualization: Min D.

Data curation: McDonald I.

Formal analysis: McDonald I, Baral R.

Methodology: McDonald I, Min D.

Software: Baral R.

Validation: Min D.

Investigation: McDonald I.

Writing - original draft: McDonald I.

Writing - review \& editing: Min D, Baral R.

Ethics approval and consent to participate This article does not require IRB/IACUC approval because there are no human and animal participants. in the fall is questionable [4], and its effect on dry matter yield (DMY) and stand persistence needs study [5-7].

Brink et al. [8], Hall et al. [9], Dhont et al. [10] and Sheaffer and Marten [6] reported that extending the last cut in the fall increases total DMY for the year, but it also has a negative impact on yield in the first cut of the next year. Also, frequent, seasonal harvests of alfalfa can impact stand persistence [11,12]. Sheaffer and Marten [6] documented that, if the last cut in the fall is before a first killing frost, the harvest does not have much of a negative effect on stand persistence for several years after the alfalfa has been planted. In contrast to these results, other studies have documented no effect of harvest time on stand persistence of alfalfa [13,14]. Belanger et al. [5] reported that DMY did not change in a third and last cut in the fall. In a study done in Michigan, Tesar [15] reported that a producer could make the last cut in the fall in October without damaging stand persistence.

Avice et al. [16], Dhont et al. [17], Hendershot and Volenec [18] and Volenec et al. [19] documented that root nitrogen $(\mathrm{N})$ reserves and storage proteins have a close relation with spring regrowth. Alfalfa persistence is affected not only by root reserves, but it also depends on the soil temperature, amount of snow during winter [20,21], the content of moisture and nutrients in the soil [22-24], age of alfalfa stands [25], and the frequency of cuttings during the season and the stage of maturity [26].

Many factors interact with harvest time in the fall, which influences DMY and stand persistence of alfalfa. Weather conditions vary from fall to fall, causing producers to harvest at different times. The first killing frost in Kansas varies tremendously but based on 30 years of weather data, it ranges from mid-September to November. In 2015 the first freeze in Manhattan, Kansas, was on October 30, in 2016 on November 12, and in 2017 on October 27. Sometimes they have a late harvest right before the first killing frost, and they do not know if it might negatively affect yield and stand. This raises the question of how to manage the forage and when is the best time to cut in the fall. The objective of this study was to evaluate the effect of the timing of the last fall harvest on DMY, nutritive value, and stand persistence of three alfalfa varieties: reduced-lignin Hi - Gest $360 \mathrm{LL}$, Roundup Ready RR Tonica, and conventional Gunner alfalfa.

\section{MATERIAL AND METHODS}

The experiment was conducted starting on April 23, 2015, at the Kansas State University Agronomy Research Farm in Manhattan, Kansas ( $39^{\circ} 20^{\prime} \mathrm{N}, 96^{\circ} 59^{\prime} \mathrm{W}$ ). The soil type at the study site was a Wymore silty clay and Smolan silt loam (fine, smectic, mesic Pachic Argiustoll) with soil $\mathrm{pH}$ 6.86, $\mathrm{P}_{2} \mathrm{O}_{5}, 54 \mathrm{ppm}, \mathrm{K}_{2} \mathrm{O} 284 \mathrm{ppm}$ [27]. Weather data were collected from an automated Kansas Mesonet Station located at the Agronomy Research Farm, which is part of the Weather Data Library and the State Climate Office [28]. Average maximum and minimum temperatures and precipitation are reported in Table 1 for the study period, April 23, 2015 to May 15, 2018.

Three different alfalfa cultivars were planted (reduced-lignin Hi - Gest 360 LL, Roundup Ready RR Tonica, and conventional Gunner alfalfa) on April 23, 2015. These cultivars are commonly grown alfalfa cultivars in Kansas which have fall dormancy 3-5 and winter survival rating 1-2 [29].

The seeding rate of each alfalfa cultivar was $20.18 \mathrm{~kg} / \mathrm{ha}$. The experimental design was a splitplot in a randomized complete block design with four replications, the varieties were considered as main factor and the last date of the cut in the fall the sub-factor. The plot size was $1 \mathrm{~m}$ wide and 3 $\mathrm{m}$ long, for a total of 48 plots. Samples were collected at the same time, which was the 1/10 bloom stage of maturity. The four different last cutting dates in the fall of 2015, 2016, and 2017 were September 15, September 30, October 15, and October 30. In 2015 and 2016, there were three cuts 
Table 1. Rainfall and maximum and minimum temperatures at North Farm, Kansas State University during the study period

\begin{tabular}{|c|c|c|c|c|c|c|c|c|c|c|c|c|}
\hline \multirow{2}{*}{ Climate Characteristics } & \multicolumn{12}{|c|}{ Month } \\
\hline & Jan. & Feb. & Mar. & Apr. & May & Jun. & Jul. & Aug. & Sep. & Oct. & Nov. & Dec. \\
\hline \multicolumn{13}{|l|}{2015} \\
\hline Monthly rain (mm) & & & & 75.2 & 274.3 & 137.4 & 139.2 & 96 & 82.3 & 17.8 & 114.3 & 70.1 \\
\hline Mean Max. temperature $\left({ }^{\circ} \mathrm{C}\right)$ & & & & 20.3 & 22.9 & 31 & 31.9 & 30.7 & 29.7 & 23.3 & 16.3 & 9.5 \\
\hline Mean Min. temperature $\left({ }^{\circ} \mathrm{C}\right)$ & & & & 7.2 & 12.2 & 18.6 & 20.8 & 17.6 & 17.3 & 8.5 & 3.3 & 1.5 \\
\hline \multicolumn{13}{|l|}{2016} \\
\hline Monthly rain (mm) & 14 & 8.6 & 9.1 & 201.7 & 150.9 & 32.3 & 176.8 & 149.6 & 156.9 & 55.1 & 10.9 & 19.1 \\
\hline Mean Max. temperature $\left({ }^{\circ} \mathrm{C}\right)$ & 4.7 & 11.9 & 18.2 & 21.2 & 23.9 & 33.2 & 32.3 & 30.4 & 28.6 & 24.1 & 17.4 & 5.6 \\
\hline Mean Min. temperature $\left({ }^{\circ} \mathrm{C}\right)$ & -5.9 & -2.4 & 3.2 & 7.9 & 11.5 & 20 & 21.5 & 19.8 & 16.5 & 9.7 & 4 & -6.4 \\
\hline \multicolumn{13}{|l|}{2017} \\
\hline Monthly rain (mm) & 34.3 & 11.7 & 100.6 & 114.8 & 91.7 & 74.4 & 38.9 & 144 & 33 & 63.8 & 3.3 & 2.8 \\
\hline Mean Max. temperature $\left({ }^{\circ} \mathrm{C}\right)$ & 6.3 & 13.5 & 15.2 & 19.4 & 24.7 & 31.2 & 33.7 & 29.1 & 29.4 & 21.6 & 14.4 & 6.8 \\
\hline Mean Min. temperature $\left({ }^{\circ} \mathrm{C}\right)$ & -4.6 & -1 & 2.9 & 7.9 & 11.6 & 17.9 & 21.1 & 16.8 & 15.7 & 7.9 & 1.6 & -5.2 \\
\hline \multicolumn{13}{|l|}{2018} \\
\hline Monthly rain (mm) & 14.2 & 14.5 & 15.2 & 38.6 & 56.6 & & & & & & & \\
\hline Mean Max. temperature $\left({ }^{\circ} \mathrm{C}\right)$ & 5.7 & 0 & 14.3 & 16.2 & 29.7 & & & & & & & \\
\hline Mean Min. temperature $\left({ }^{\circ} \mathrm{C}\right)$ & -7.4 & -6.7 & 0.7 & 1.5 & 15.1 & & & & & & & \\
\hline
\end{tabular}

before the last cut on May 23, June 25, and August 6. But in 2017, there were four cuts before the last cut on May 20, June 23, July 25, and August 29 because of fast regrowth in this year. Forage samples were collected by clipping plants with shears within a $0.18 \mathrm{~m}^{2}$ quadrat, randomly placed, and the number of the live plants per quadrat in each plot were counted in the fall of 2015, in the spring and fall of 2016, in the spring and fall of 2017, and in the spring of 2018 (on May 10,2018). The biomass was collected from each plot for estimation of yield and stand persistence. The samples collected during 2016 and 2017 were also analyzed for forage quality (crude protein [CP], acid detergent fiber $[\mathrm{ADF}]$, neutral detergent fiber $[\mathrm{NDF}]$, and relative feed value $[\mathrm{RFV}]$ ), as described below.

\section{Dry matter yield and stand persistence}

Samples were collected, placed into paper bags, and put in a cooler; bags were taken out of the cooler, weighed, and placed in a dryer at $60^{\circ} \mathrm{C}$ for 72 hours and dried to constant weight to determine percent moisture (dry matter) and DMY.The DMY was calculated as follows:

$$
\operatorname{DMY}(\%)=(\text { Dry weight of sample } / \text { Original fresh weight of sample }) \times 100
$$

To evaluate stand persistence, stand density was used, which is the common method to determine stand persistence. Every fall and spring during the study, plants were counted in the randomly placed quadrat $\left(0.18 \mathrm{~m}^{2}\right)$ in each plot.

\section{Nutritive values}

The samples were dried and ground in a Wiley mill with a $1 \mathrm{~mm}$ screen and were analyzed for $\mathrm{ADF}$ and NDF analysis using the method of Van Soest et al. [30]. CP was calculated by multiplying the total nitrogen in the forage samples 6.25 [31]. The dry samples were ground in a Wiley mill with a $1 \mathrm{~mm}$ screen. Total nitrogen in the samples was determined by the Soil Testing Laboratory at Kansas State University. The laboratory digests the samples using a sulfuric peroxide 
acid digestion, and then the digest is analyzed for nitrogen by a colorimetric procedure using the Rapid Flow Analyzer (Model RFA-300, Alpkem, Clackamas, OR, USA) and RFA Methodology No. A303-S072 (Alpkem). CP in percent was calculated by multiplying the total nitrogen (\%) by 6.25 .

RFV is calculated from digestible dry matter digestibility (DMD) and dry matter intake (DMI) using $\mathrm{ADF}(\%)$ and $\mathrm{NDF}(\%)$, respectively [32]. Using the equations of Rohweder et al. [32], the $\mathrm{RFV}$ of legume-grass mixtures and monocultures was calculated as follows:

$$
\begin{gathered}
\operatorname{DMD}(\%)=88.9-(0.779 \times \mathrm{ADF}) \\
\mathrm{DMI}(\%)=120 /(\mathrm{NDF}) \\
\mathrm{RFV}=(\mathrm{DMD} \times \mathrm{DMI}) / 1.29
\end{gathered}
$$

\section{Statistical analysis}

Statistical analyses were done using a mixed-effects model in PROC GLIMMIX [33]. An ANOVA for variables was conducted for each year and each cut with the three varieties and four last cutting dates in the fall as a fixed effect. The varieties were considered as the main factor and the last date of the cut in the fall was the sub-factor. Mean separation was performed using the Bonferroni correction All statistical comparisons were made at the $\alpha=0.05$ probability level.

\section{RESULTS AND DISCUSSION}

The study evaluated the effect of the timing of a fall cut in Kansas on DMY, nutritive value, stand persistence, and three alfalfa varieties: low-lignin $\mathrm{Hi}-\mathrm{Gest} 360 \mathrm{LL}$, roundup ready RR Tonica, and conventional Gunner alfalfa. The environmental conditions in Kansas in 2016 and 2017 (Table 1) were similar, except precipitation in the summer of 2017 was less than during the summer of 2016.

\section{Dry matter yield and stand persistence}

For the last fall cut in 2015, 2016, and 2017, a last cut and year interaction occurred for DMY and stand persistence but there was no interaction between last cut and variety. Same result was found in the first cut in 2016,2017, and 2018 (Table 2).

In 2016, the field was cut four times and in 2017 it was cut five times. Bélanger et al. [34] observed that taking an additional fall cut will decrease winter survival and DMY in the following year. In the last cut in the fall and the first cut in the following year, no significant difference was found in DMY among Roundup Ready alfalfa, Gunner alfalfa, and reduced-lignin alfalfa (Table 2). A significantly $(p<0.05)$ higher yield was observed with the last cut of September 15 (3.3 Mg/ ha) than in other cutting dates. The lowest yield was found in the last cut on October 30 (2.2 Mg/ ha) (Table 2). In 2016, differences in DMY in the first cut in the spring were not seen, even though plots had been cut on four different dates in the last cut in the previous year.

However, it was observed that DMY decreased as the years progressed. This was true both for the last cuts on September 15, September 30, October 15, and October 30 in 2015, 2016, 2017 and the first cuts of each year in 2016, 2017, 2018 (Table 3). In the first cut of 2016, the DMY was higher than the DMY of the first cut in 2017 and 2018 (Table 3). A similar observation was made by Dhont et al. [10], who found in a field study that a fall cut had negative impact on stand persistence and yield the next year. Taking an additional cut not only increases the risk of winterkill but also decreases DMY in the next year. In general, an additional cut increases the total DMY for the year, but this increases the risk of winterkill.

Our results showed that DMY in the first cut in the spring in 2017 and 2018 in plots that been 
Table 2. Yield of the plants per $0.18 \mathrm{~m}^{2}$ in falls of 2015, 2016, and 2017 and springs of 2016, 2017, and 2018

\begin{tabular}{|c|c|c|c|}
\hline & Yield (Mg/ha) & & Yield (Mg/ha) \\
\hline Year & & Year & \\
\hline Fall 2015 & $2.7^{\mathrm{b}}$ & Spring 2016 & $6.8^{\mathrm{a}}$ \\
\hline Fall 2016 & $3.5^{\mathrm{a}}$ & Spring 2017 & $3.4^{\mathrm{b}}$ \\
\hline Fall 2017 & $1.7^{\mathrm{c}}$ & Spring 2018 & $2.8^{\mathrm{c}}$ \\
\hline Variety & & Variety & \\
\hline RA & $2.6^{\mathrm{a}}$ & RA & $4.4^{\mathrm{a}}$ \\
\hline A & $2.7^{\mathrm{a}}$ & A & $4.4^{\mathrm{a}}$ \\
\hline LA & $2.5^{\mathrm{a}}$ & LA & $4.2^{\mathrm{a}}$ \\
\hline Last cut in fall & & First cut in spring & \\
\hline 15-Sep & $2.4^{\mathrm{bc}}$ & 15-Sep & $4.4^{\mathrm{a}}$ \\
\hline 30-Sep & $3.3^{\mathrm{a}}$ & 30-Sep & $4.5^{\mathrm{a}}$ \\
\hline 15-Oct & $2.6^{\mathrm{b}}$ & 15-Oct & $4.4^{\mathrm{a}}$ \\
\hline $30-O c t$ & $2.2^{c}$ & 30-Oct & $4.1^{\mathrm{a}}$ \\
\hline Last cut in fall (p-value) & & First cut in spring ( $p$-value) & \\
\hline Last cut & $* * *$ & Last cut & NS \\
\hline Year & $* \star *$ & Year & $* * *$ \\
\hline Variety & NS & Variety & NS \\
\hline Year $\times$ Last cut & *** & Year $\times$ Last cut & NS \\
\hline Variety $\times$ Last cut & NS & Variety $\times$ Last cut & NS \\
\hline
\end{tabular}

${ }^{a-c}$ Different letters in the same column are significant at $\alpha$ level 0.05 .

*** Significant at a level of 0.01 .

RA, Roundup Ready Tonica alfalfa; A, Gunner conventional alfalfa; LA, low-lignin Hi-Gest 360 alfalfaa; NS, not significant.

Table 3. Yield (Mg/ha) comparison in last cuts in falls of 2015, 2016 and 2017, and first cuts in springs of 2016, 2017, and 2018

\begin{tabular}{lccccccc}
\hline Last cut in fall & $\mathbf{2 0 1 5}$ & $\mathbf{2 0 1 6}$ & $\mathbf{2 0 1 7}$ & First cut in spring & $\mathbf{2 0 1 6}$ & $\mathbf{2 0 1 7}$ & $\mathbf{2 0 1 8}$ \\
\hline $15-$ Sep & $2.6^{\mathrm{a}}$ & $3.3^{\mathrm{b}}$ & $1.2^{\mathrm{a}}$ & $15-$ Sep & $6.9^{\mathrm{a}}$ & $3.4^{\mathrm{a}}$ & $2.8^{\mathrm{b}}$ \\
$30-$ Sep & $3.5^{\mathrm{b}}$ & $4.4^{\mathrm{c}}$ & $2.0^{\mathrm{b}}$ & $30-$ Sep & $7.1^{\mathrm{a}}$ & $3.3^{\mathrm{a}}$ & $3.0^{\mathrm{b}}$ \\
15-Oct & $2.4^{\mathrm{a}}$ & $3.7^{\mathrm{b}}$ & $1.8^{\mathrm{b}}$ & $15-$ Oct & $6.4^{\mathrm{a}}$ & $3.8^{\mathrm{a}}$ & $2.9^{\mathrm{b}}$ \\
30-Oct & $2.3^{\mathrm{a}}$ & $2.6^{\mathrm{a}}$ & $1.7^{\mathrm{b}}$ & $30-$ Oct & $6.7^{\mathrm{a}}$ & $3.3^{\mathrm{a}}$ & $2.3^{\mathrm{a}}$ \\
\hline
\end{tabular}

${ }^{a, b}$ Different letters in the same column are significant at $\alpha$ level of either 0.05 or 0.01 .

harvested in the fall of the previous year on October 30 was lower than DMY in other plots (Table 2). In 2015 the highest yield was in plots that been cut on September 30 (3.5 Mg/ha). In 2016 the significantly highest yield was in plots that were harvested on September 30 (4.4 Mg/ha), which was the highest DMY for the three years of data.

In the last cuts, a significantly higher number of live plants was in plots that were harvested on September 15 (19 live plants), and the lowest stand persistence was observed in plots that were harvested on October 15 and October 30 (October 15-15 live plants and October 30-14 live plants) (Table 4 and 5). In the first cuts in the springs of 2016 and 2017, the higher number of live plants was found in plots that been cut in the fall of the previous year on September 15, and in the spring of 2018, the highest number of live plants was found in the plots that were cut on September 15 and September 30 in the previous year, and they each had the same number of live plants (14 per $\left.0.18 \mathrm{~m}^{2}\right)$. The lowest number was found in plots that were cut on October 30 in the previous year $\left(10\right.$ per $\left.0.18 \mathrm{~m}^{2}\right)$.

Several studies $[16,18,19]$ have shown that a fall cut has a close relationship with the storage of 
Table 4. Number of the plants per $0.18 \mathrm{~m}^{2}$ in falls of 2015, 2016, and 2017, and springs of 2016, 2017, and 2018

\begin{tabular}{|c|c|c|c|}
\hline Last cut in fall & Plants number & First cut in spring & Plants number \\
\hline Variety & & lariety & \\
\hline RA & $19^{\mathrm{a}}$ & RA & $16^{\mathrm{b}}$ \\
\hline$A$ & $18^{\mathrm{a}}$ & A & $17^{\mathrm{a}}$ \\
\hline LA & $18^{\mathrm{a}}$ & LA & $15^{\mathrm{b}}$ \\
\hline Last cut in fall & & irst cut in spring & \\
\hline 15-Sep & $21^{\mathrm{a}}$ & 15-Sep & $18^{\mathrm{a}}$ \\
\hline 30-Sep & $18^{b}$ & 30-Sep & $17^{b}$ \\
\hline $15-$-Oct & $16^{b}$ & $15-O c t$ & $14^{\mathrm{c}}$ \\
\hline 30-Oct & $18^{\mathrm{b}}$ & 30-Oct & $14^{c}$ \\
\hline Year & & ear & \\
\hline Fall 2015 & $20^{\mathrm{a}}$ & Spring 2016 & $19^{\mathrm{a}}$ \\
\hline Fall 2016 & $19^{b}$ & Spring 2017 & $16^{\mathrm{b}}$ \\
\hline Fall 2017 & $16^{c}$ & Spring 2018 & $12^{c}$ \\
\hline \multicolumn{4}{|l|}{$p$-value } \\
\hline Last cut & $* \star \star$ & Last cut & $* \star *$ \\
\hline Year & $\star \star \star *$ & Year & $\star \star \star *$ \\
\hline Variety & NS & Variety & $* *$ \\
\hline Year $\times$ Last cut & 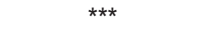 & Year $\times$ Last cut & $* \star *$ \\
\hline Variety $\times$ Last cut & NS & Variety $\times$ Last cut & NS \\
\hline
\end{tabular}

${ }^{a-c}$ Different letters in the same column are significant at a level of either 0.05 or 0.01 .

**Significant at a level of 0.05 and ${ }^{* * *}$ Significant at $\alpha$ level of 0.01 .

RA, Roundup Ready Tonica alfalfa; A, Gunner conventional alfalfa; LA, low-lignin Hi-Gest 360 alfalfa; NS, not significant.

Table 5. Number of the plants per $0.18 \mathrm{~m}^{2}$ in last cuts of 2015, 2016 and 2017, and first cuts of 2016, 2017, and 2018

\begin{tabular}{lccccccc}
\hline \multicolumn{1}{c}{ Last cut in fall } & $\mathbf{2 0 1 5}$ & $\mathbf{2 0 1 6}$ & $\mathbf{2 0 1 7}$ & First cut in spring & $\mathbf{2 0 1 6}$ & $\mathbf{2 0 1 7}$ & $\mathbf{2 0 1 8}$ \\
\hline 15-Sep & $22^{\mathrm{b}}$ & $22^{\mathrm{b}}$ & $19^{\mathrm{b}}$ & $15-$ Sep & $22^{\mathrm{c}}$ & $20^{\mathrm{c}}$ & $14^{\mathrm{c}}$ \\
$30-$ Sep & $19^{\mathrm{a}}$ & $19^{\mathrm{a}}$ & $17^{\mathrm{b}}$ & $30-$ Sep & $19^{\mathrm{ab}}$ & $17^{\mathrm{b}}$ & $14^{\mathrm{c}}$ \\
15-Oct & $18^{\mathrm{a}}$ & $17^{\mathrm{a}}$ & $15^{\mathrm{a}}$ & $15-$ Oct & $17^{\mathrm{a}}$ & $15^{\mathrm{a}}$ & $12^{\mathrm{e}}$ \\
$30-$ Oct & $22^{\mathrm{b}}$ & $19^{\mathrm{a}}$ & $14^{\mathrm{a}}$ & $30-$ Oct & $19^{\mathrm{ab}}$ & $14^{\mathrm{a}}$ & $10^{\mathrm{b}}$ \\
\hline
\end{tabular}

${ }^{a-e}$ Different letters in the same column are significant at $\alpha$ level of either 0.05 or 0.01 .

root reserves and regrowth of alfalfa in the spring [35]. However, in our study, we did not measure root reserves. Our results agree with those of Schoner [36] and Sheaffler et al. [37] who reported that DMY and stand persistence decreased if the last fall cut was delayed.

McKenzie and McLean [21] documented that, as alfalfa plants get older, they are more susceptible to winter kill than the younger alfalfa plants. A similar observation was made in our study in the first cut in 2018, when the stand persistence decreased by $36 \%$ in plots that were harvested on September 15, and by 26\% in plots were harvested on September 30. The highest reduction in stand persistence of $47 \%$ was observed in plots that were harvested on October 30. Differences in stand persistence and DMY among the alfalfa varieties were not found in our study.

Parsons and Davis [38] observed in Ohio that, when alfalfa was harvested five times per year, plants were damaged more than plants that been cut three times per year. Similar studies were done in Minnesota by Brink and Marten [39] and Timble et al. [40]. Min [41] in Kansas recommended reducing five cuttings to four as well. 


\section{Annual total dry matter yield in the first and second production years}

The means of each cutting and total yield in 2016 and 2017 were shown in Table 6. In the first cut in 2016, the highest DMY was observed in Roundup Ready alfalfa $(7.3 \mathrm{Mg} / \mathrm{ha})$, and the lowlignin alfalfa produced the lowest yield (6.1 Mg/ha). Plots harvested in 2015 on September 15, September 30, October 15, and October 30 showed no differences in yield in the first and second cuts of 2016. Conventional Gunner alfalfa had significantly $(p<0.05)$ higher DMY in the second cut of 2016 (4.1 Mg/ha) than Roundup Ready alfalfa $(2.1 \mathrm{Mg} / \mathrm{ha})$. In the third cut, no significant differences were found in DMY among the varieties and the dates of the last cuttings in the fall. But in the fourth cut of 2016 in plots that were harvested on September 30, the DMY was significantly $(p<0.05)$ higher $(4.3 \mathrm{Mg} / \mathrm{ha})$ than in plots that were harvested on October $30(2.6$ $\mathrm{Mg} / \mathrm{ha}$ ), but no significant differences were found among the varieties.

In 2017, no significant differences were observed for plots harvested on September 15, September 30, October 15, and October 30, and no significant differences were observed in DMY among the three varieties at these harvest times. In the second cut of 2017, no significant differences in yield among the alfalfa varieties were found, but the plots that were harvested in the fall on September $15 \mathrm{had}$ a significantly higher DMY (3.2 Mg/ha) than plots that were harvested on October 30 (2.6 Mg/ha) (Table 6). In the third cut of 2017, no significant differences were found in DMY among the varieties and the dates of last cuttings in the fall did not affect DMY. In the fourth cut of 2017, the plots that were harvested on October 30 had a significantly $(p<0.05)$ lower DMY, which was similar to the fourth cut in 2016 (2.7 Mg/ha). The highest yield was found in plots that were harvested in the fall on September $15(3.7 \mathrm{Mg} / \mathrm{ha}$ ) (Table 6).

Based on two years of data (2016 and 2017), no significant differences in total DMY were found among the alfalfa varieties. The total DMY in 2017 decreased by 12\% in Roundup Ready RR Tonica alfalfa, 21\% in Gunner conventional alfalfa, and $19 \%$ in reduced-lignin Hi-Gest 360 LL alfalfa compared to the total yield in 2016 (Table 6). A significantly lower total DMY was found in plots that were harvested on October 30 in both years 2016 and 2017. The highest total DMY was in plots that were harvested on September 30 in both years. Two of the main factors that control

Table 6. Mean and total dry matter yield (Mg/ha) in 2016 and 2017

\begin{tabular}{|c|c|c|c|c|c|c|c|c|c|c|c|}
\hline & \multicolumn{5}{|c|}{2016} & \multicolumn{6}{|c|}{2017} \\
\hline & Cut 1 & Cut 2 & Cut 3 & Cut 4 & Total & Cut1 & Cut 2 & Cut 3 & Cut 4 & Cut 5 & Total \\
\hline \multicolumn{12}{|l|}{ Variety } \\
\hline$A$ & $7.0^{\mathrm{ab}}$ & $4.1^{\mathrm{a}}$ & $2.7^{\mathrm{a}}$ & $3.7^{\mathrm{a}}$ & $17.5^{\mathrm{a}}$ & $3.3^{\mathrm{a}}$ & $3.0^{\mathrm{a}}$ & $2.6^{a}$ & $3.3^{\mathrm{a}}$ & $1.7^{\mathrm{a}}$ & $13.9^{a}$ \\
\hline LA & $6.1^{b}$ & $3.5^{\mathrm{ab}}$ & $3.7^{\mathrm{a}}$ & $3.5^{\mathrm{a}}$ & $16.8^{\mathrm{a}}$ & $3.6^{\mathrm{a}}$ & $2.8^{\mathrm{a}}$ & $2.4^{\mathrm{a}}$ & $3.2^{\mathrm{a}}$ & $1.6^{\mathrm{a}}$ & $13.6^{a}$ \\
\hline 30-Sep & $7.1^{a}$ & $3.6^{a}$ & $3.2^{\mathrm{a}}$ & $4.3^{\mathrm{a}}$ & $18.2^{\mathrm{a}}$ & $3.3^{\mathrm{a}}$ & $3.1^{\mathrm{ab}}$ & $2.8^{a}$ & $3.6^{\mathrm{ab}}$ & $2.0^{\mathrm{a}}$ & $14.8^{a}$ \\
\hline 15-Oct & $6.4^{\mathrm{a}}$ & $2.9^{\mathrm{a}}$ & $3.0^{\mathrm{a}}$ & $3.7^{\mathrm{ab}}$ & $16.0^{\mathrm{ab}}$ & $3.8^{\mathrm{a}}$ & $2.9^{\mathrm{ab}}$ & $2.2^{\mathrm{a}}$ & $3.1^{\mathrm{bc}}$ & $1.8^{\mathrm{ab}}$ & $13.8^{\mathrm{ab}}$ \\
\hline 30-Oct & $6.7^{\mathrm{a}}$ & $3.2^{\mathrm{a}}$ & $3.0^{\mathrm{a}}$ & $2.6^{c}$ & $15.5^{\mathrm{b}}$ & $3.3^{\mathrm{a}}$ & $2.6^{b}$ & $2.3^{\mathrm{a}}$ & $2.7^{c}$ & $1.7^{\mathrm{b}}$ & $12.6^{b}$ \\
\hline \multicolumn{12}{|l|}{$p$-value } \\
\hline
\end{tabular}

${ }^{a-c}$ Different letters in the same column are significant at $\alpha$ level of either 0.05 or 0.01 .

${ }^{* *}$ Significant at $\alpha$ level of 0.05 and ${ }^{* * *}$ Significant at $\alpha$ level of 0.01 .

RA, Roundup Ready Tonica alfalfa; A, Gunner conventional alfalfa; LA, low-lignin Hi-Gest 360 alfalfa; NS, not significant. 
DMY of alfalfa and nutritive value are frequency of shoot removal $[8,42,43]$ and stand persistence $[39,44]$. In our study was observed that in the first cuttings in 2016 and 2017 the DMY was the highest and decreased by end of the year. During the four seasonal cuttings in 2016, the dry matter was higher compared to five seasonal cuttings in 2017. The frequent cuttings increased the forage nutritive value and reduced the stand persistence of alfalfa. Based on the results of this study, it appears that the last cutting of alfalfa can be done by September 30 without yield reduction.

\section{Nutritive value}

\section{Crude protein}

The means and average CP of each cut in 2016 and 2017 were shown in Table 7. In the first cut, second cut, and third cut in 2016, no significant $(p<0.05)$ differences in CP were found among the alfalfa varieties. Also, no differences in $\mathrm{CP}$ were found among the plots harvested on September 15, September 30, October 15, and October 30. For the fourth cut in 2016, conventional Gunner alfalfa had the lowest CP concentration $164 \mathrm{~g} / \mathrm{kg}$ DM and reduced-lignin Hi - Gest $360 \mathrm{LL}$ alfalfa the highest CP concentration $181 \mathrm{~g} / \mathrm{kg}$ DM. Alfalfa harvested in the fall on October $30 \mathrm{had}$ a significantly $(p<0.05)$ lower CP concentration compared to plots harvested on other dates. It been reported that frequent cuttings had an earlier stage of maturity, and as the cutting delayed the higher maturity of alfalfa, and the CP concentration decreases [9,41,45].

In 2017, no significant differences in CP were found among the varieties for the first, second, third and fourth cuts. Also, no significant differences in CP were found in alfalfa harvested on September 15, September 30, October 15 and October 30. In the fifth cut in 2017, no significant $(p<0.05)$ differences were found among the alfalfa varieties, but significant $(p<0.05)$ differences in $\mathrm{CP}$ concentration were observed for alfalfa in the last cut. The highest $\mathrm{CP}$ concentration $(351 \mathrm{~g} / \mathrm{kg}$ $\mathrm{DM})$ was in plots that were cut on September 15 , and the lowest CP $(235 \mathrm{~g} / \mathrm{kg} \mathrm{DM})$ was in plots that were cut on October 30.

The average CP concentration in 2016 was higher $(184 \mathrm{~g} / \mathrm{kg}$ DM) in Roundup Ready RR Tonica alfalfa, and the lowest CP concentration (176 g/kg DM) was in conventional Gunner

Table 7. Mean CP concentration (g/kg DM) in 2016 and 2017

\begin{tabular}{|c|c|c|c|c|c|c|c|c|c|c|c|}
\hline & \multicolumn{5}{|c|}{2016} & \multicolumn{6}{|c|}{2017} \\
\hline & Cut 1 & Cut 2 & Cut 3 & Cut 4 & Average & Cut1 & Cut 2 & Cut 3 & Cut 4 & Cut 5 & Average \\
\hline \multicolumn{12}{|l|}{ Variety } \\
\hline RA & $192^{\mathrm{a}}$ & $178^{a}$ & $19^{a}$ & $177^{\mathrm{ab}}$ & $184^{\mathrm{a}}$ & $224^{a}$ & $281^{a}$ & $268^{a}$ & $259^{a}$ & $287^{\mathrm{a}}$ & $264^{a}$ \\
\hline A & $197^{a}$ & $162^{\mathrm{ab}}$ & $179^{a}$ & $164^{b}$ & $176^{\mathrm{b}}$ & $217^{\mathrm{a}}$ & $255^{\mathrm{a}}$ & $255^{\mathrm{a}}$ & $251^{a}$ & $280^{a}$ & $252^{\mathrm{a}}$ \\
\hline LA & $199^{a}$ & $173^{a}$ & $179^{a}$ & $181^{a}$ & $183^{\mathrm{ab}}$ & $228^{a}$ & $281^{a}$ & $268^{a}$ & $252^{a}$ & $289^{a}$ & $264^{a}$ \\
\hline \multicolumn{12}{|l|}{ Last cut } \\
\hline 15-Sep & $190^{\mathrm{a}}$ & $173^{a}$ & $175^{\mathrm{a}}$ & $181^{a}$ & $180^{a}$ & $225^{\mathrm{a}}$ & $281^{a}$ & $262^{a}$ & $269^{a}$ & $351^{a}$ & $278^{a}$ \\
\hline 30-Sep & $197^{\mathrm{a}}$ & $174^{a}$ & $185^{a}$ & $178^{a}$ & $183^{a}$ & $226^{a}$ & $265^{a}$ & $259^{a}$ & $258^{a}$ & $288^{b}$ & $259^{b}$ \\
\hline 15-Oct & $198^{a}$ & $172^{a}$ & $180^{a}$ & $177^{\mathrm{a}}$ & $182^{a}$ & $215^{\mathrm{a}}$ & $260^{a}$ & $260^{a}$ & $245^{a}$ & $268^{c}$ & $250^{b}$ \\
\hline 30-Oct & $197^{\mathrm{a}}$ & $166^{a}$ & $192^{\mathrm{a}}$ & $159^{b}$ & $179^{\mathrm{a}}$ & $225^{\mathrm{a}}$ & $280^{a}$ & $274^{a}$ & $244^{a}$ & $235^{d}$ & $252^{\mathrm{b}}$ \\
\hline \multicolumn{12}{|l|}{$p$-value } \\
\hline Variety & NS & NS & NS & $* *$ & NS & NS & NS & NS & NS & NS & NS \\
\hline Last cut & NS & NS & NS & $* *$ & NS & NS & NS & NS & NS & $* * *$ & $* * *$ \\
\hline Variety $\times$ Last cut & NS & NS & NS & NS & NS & NS & NS & NS & NS & NS & NS \\
\hline
\end{tabular}


alfalfa. In the plots that were cut on September 15, September 30, October 15 and October 30, no differences in CP were found. In 2017 no differences were found among alfalfa varieties in CP concentration. Rimi et al. [46] noted that alfalfa harvested at an early stage of maturity provided a higher nutritive value than alfalfa harvested at a later stage of maturity. Similar results were found in our study for the data of 2017. The results showed that the highest CP content $(278 \mathrm{~g} / \mathrm{kg} \mathrm{DM})$ was found in plots that were cut on September 15. Min [41] observed that cutting frequency affects the nutritive values of the alfalfa, and our results agree with his. In 2016, the alfalfa was harvested four times, and in 2017 it was harvested five times. Because of the number of harvests, CP concentration was much higher in 2017 than in 2016. The average data showed that $\mathrm{CP}$ was higher with five cuts in 2017 than with four cuts in 2016.

\section{Acid detergent fiber}

The means and average ADF of each cut in 2016 and 2017 were shown in Table 8. There was a varietal difference in $\mathrm{ADF}$. The $\mathrm{ADF}$ concentration in the first cut in 2016 was significantly $(p<$ 0.05 ) higher in conventional Gunner alfalfa (326 g/ $\mathrm{kg} \mathrm{DM})$, and the lowest ADF concentration was found in low-lignin Hi - Gest $360 \mathrm{LL}$ alfalfa $(279 \mathrm{~g} / \mathrm{ka} \mathrm{DM})$. Similar results were found in the second cut in 2016. A higher ADF concentration (346 g/ $\mathrm{kg} \mathrm{DM}$ ) was found in Gunner alfalfa, and the reduced-lignin $\mathrm{Hi}$ - Gest $360 \mathrm{LL}$ alfalfa had the lowest ADF concentration $(297 \mathrm{~g} / \mathrm{kg}$ $\mathrm{DM})$. The last date of cuttings in the fall did not affect the ADF content in the first and second cuts in 2016. In the third and fourth cuts in 2016, the ADF concentration was significantly $(p<$ 0.05 ) lower in reduced-lignin $\mathrm{Hi}$ - Gest $360 \mathrm{LL}$ alfalfa compared to the other two varieties of alfalfa. In the third cut, the plots that been cut on September 15 in the previous year had an ADF concentration that was significantly $(p<0.05)$ higher than ADF concentration in plots that had been cut on October 15. But in the fourth cut of 2016 on September 15, September 30, October 15 , or October 30, the lowest $\mathrm{ADF}$ concentration was found in plots that were cut on September $15(329 \mathrm{~g} / \mathrm{kg} \mathrm{DM})$, and the highest ADF concentration was in plots that been cut on October 30 $(356 \mathrm{~g} / \mathrm{kg} \mathrm{DM})$.

Table 8. Mean ADF concentration (g/kg DM) in 2016 and 2017

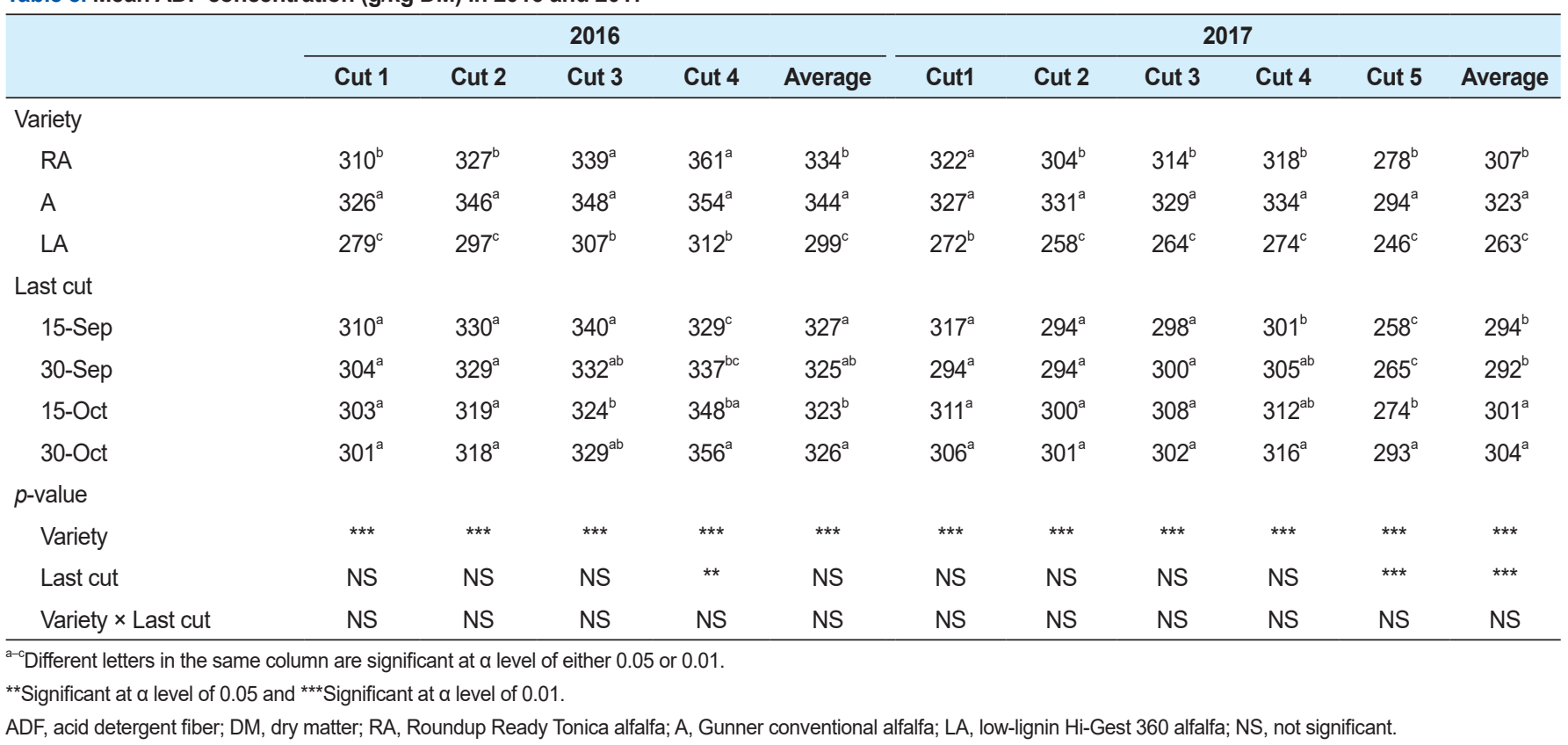


In 2017 in the first cut, the lowest ADF concentration was found in the low-lignin $\mathrm{Hi}$ - Gest $360 \mathrm{LL}$ alfalfa $(272 \mathrm{~g} / \mathrm{kg} \mathrm{DM})$, and Gunner alfalfa and RR Tonica alfalfa had the highest ADF concentration. In the second, third, fourth and fifth cuts of 2017, the reduced-lignin Hi - Gest 360 LL alfalfa had the lowest ADF concentration, and the conventional variety Gunner had the highest $\mathrm{ADF}$ concentration. In the first, second, and third cuts, no differences in $\mathrm{ADF}$ concentration were observed, but in the fourth cut, the plots that were cut on September 15 had a significantly $(p<$ 0.05) lower ADF concentration ( $301 \mathrm{~g} / \mathrm{kg} \mathrm{DM})$, and the plots that were cut on October 30 had the highest $\mathrm{ADF}$ (316 g/kg DM). In the fifth cut of 2017, the plots that were cut on September 15 and September 30 had the lowest ADF concentration, and the highest ADF concentration was in plots that were cut on October 30.

It has been documented that forage quality decreases if the DMY of alfalfa increases and they are related to the stage of maturity of alfalfa $[8,42]$. The effect stage of maturity when alfalfa is harvested on forage nutritive values has been noted by Hall et al. [9], Kallenbach et al. [42] and Smith [3] documented that, as plants mature, the stem mass increases more than the leaf mass, which leads to a reduction of the nutritive value of the alfalfa. In 2016 and 2017, ADF concentrations were found to be lowest in plots that were cut in the fall of the previous year on September 15 and September 30 and the highest in plots that were cut on October 15 and October 30.

According to Grev et al. [47], the low-lignin alfalfa can be harvested with a delay in five days and still maintain a higher forage quality compared to other varieties of alfalfa. In our study, we found a significantly $(p<0.05)$ lower ADF concentration in low-lignin Hi - Gest $360 \mathrm{LL}$ alfalfa, and the highest $\mathrm{ADF}$ concentration was in the conventional Gunner alfalfa. The Roundup Ready RR Tonica alfalfa had a slightly lower ADF concentration than the conventional Gunner alfalfa, and a higher ADF concentration than the low-lignin Hi - Gest 360 LL alfalfa. Even in 2016 when the alfalfa was harvested four times per season, the reduced-lignin Hi- Gest $360 \mathrm{LL}$ alfalfa variety still maintained lowest the ADF concentration. In 2016 the average ADF was $299 \mathrm{~g} / \mathrm{kg} \mathrm{DM}$, and in 2017 the average ADF under five cuttings was $263 \mathrm{~g} / \mathrm{kg}$ DM. The ADF difference between alfalfa varieties was probably due to the difference in rainfall during seasonal cutting in 2016 and 2017 as well since 2017 was dryer compared to 2016 (Table 1).

\section{Neutral detergent fiber (NDF)}

The means and average NDF of each cut in 2016 and 2017 are shown in Table 9. The NDF concentration in the first cut in 2016 was significantly $(p<0.05)$ lower in the low-lignin Hi Gest $360 \mathrm{LL}$ alfalfa $(369 \mathrm{~g} / \mathrm{kg} \mathrm{DM})$ than in other two varieties. In the second cut, the low-lignin Hi-Gest 360 LL alfalfa had the lowest NDF, and the highest was found in conventional Gunner alfalfa. Results for the second cut in 2016 were similar to the third cut in 2016, and the low-lignin variety of alfalfa had a significantly $(p<0.05)$ lower NDF concentration than conventional Gunner alfalfa and Roundup Ready RR Tonica alfalfa. In the fourth cut, the lowest NDF concentration was observed in the reduced-lignin alfalfa $(392 \mathrm{~g} / \mathrm{kg} \mathrm{DM})$. For the plots that were cut in the last harvest in the fall on September 15 and September 30 in the previous year, in the first and second cuts in 2016 the highest NDF concentrations were found, and the lowest NDF concentrations were in plots that were cut on October 15 and October 30. In the third cut in 2016, the highest NDF was found in plots that had a last cut in the fall on September $15(429 \mathrm{~g} / \mathrm{kg} \mathrm{DM})$ and the lowest NDF concentration was found in the plots that were cut in October 15 (416 g/ $/ \mathrm{gg} \mathrm{DM})$. In the fourth cut in 2016, no significant differences in NDF concentration were found among the plots that were cut on September 15, September 30, October 15, and October 30. This was probably influenced by temperature and rainfall in September 2016 (Table 1) and the frequency of cutting per season. A previous study documented that NDF concentration increase if alfalfa was cut four times per year 
Table 9. Mean NDF concentration (g/kg DM) in 2016 and 2017

\begin{tabular}{|c|c|c|c|c|c|c|c|c|c|c|c|}
\hline & \multicolumn{5}{|c|}{2016} & \multicolumn{6}{|c|}{2017} \\
\hline & Cut 1 & Cut 2 & Cut 3 & Cut 4 & Average & Cut1 & Cut 2 & Cut 3 & Cut 4 & Cut 5 & Average \\
\hline \multicolumn{12}{|l|}{ Variety } \\
\hline$A$ & $409^{a}$ & $436^{a}$ & $433^{a}$ & $463^{\mathrm{a}}$ & $435^{\mathrm{a}}$ & $428^{a}$ & $421^{a}$ & $430^{\mathrm{a}}$ & $436^{\mathrm{a}}$ & $396^{\mathrm{a}}$ & $422^{\mathrm{a}}$ \\
\hline LA & $369^{b}$ & $386^{c}$ & $404^{b}$ & $410^{c}$ & $392^{c}$ & $371^{\mathrm{b}}$ & $372^{c}$ & $371^{c}$ & $375^{c}$ & $360^{c}$ & $370^{c}$ \\
\hline 30-Sep & $406^{a}$ & $420^{a}$ & $420^{\mathrm{ab}}$ & $436^{a}$ & $421^{a}$ & $402^{\mathrm{a}}$ & $398^{\mathrm{a}}$ & $396^{\mathrm{b}}$ & $408^{a}$ & $369^{b}$ & $395^{\mathrm{b}}$ \\
\hline $15-$ Oct & $386^{b}$ & $406^{b}$ & $416^{b}$ & $443^{a}$ & $413^{b}$ & $413^{a}$ & $392^{\mathrm{a}}$ & $400^{b}$ & $409^{a}$ & $388^{a}$ & $400^{a}$ \\
\hline 30-Oct & $382^{b}$ & $406^{\mathrm{b}}$ & $419^{\mathrm{ab}}$ & $441^{a}$ & $413^{b}$ & $407^{a}$ & $404^{a}$ & $410^{\mathrm{a}}$ & $413^{\mathrm{a}}$ & $391^{\mathrm{a}}$ & $405^{\mathrm{a}}$ \\
\hline \multicolumn{12}{|l|}{$p$-value } \\
\hline
\end{tabular}

${ }^{a-c}$ Different letters in the same column are significant at a level of either 0.05 or 0.01 .

**Significant at a level of 0.05 and ***Significant at a level of 0.01 .

NDF, neutral detergent fiber; DM, dry matter; RA, Roundup Ready Tonica alfalfa; A, Gunner conventional alfalfa; LA, low-lignin Hi-Gest 360 alfalfa; NS, not significant.

[42]. Since the cutting interval is extended the alfalfa gets mature, and the nutritive value of alfalfa decreases $[43,48]$.

In 2017 in the first cut, the results showed that the reduced-lignin Hi - Gest 360 LL alfalfa had a lower NDF concentration ( $371 \mathrm{~g} / \mathrm{kg} \mathrm{DM})$ than conventional Gunner alfalfa and Roundup Ready RR Tonica alfalfa. In the second, third, fourth and fifth cuts, the reduced-lignin Hi - Gest $360 \mathrm{LL}$ alfalfa had the lowest NDF, and the highest NDF was found in conventional Gunner alfalfa. For the plots that were cut in the fall on four different dates, no differences in NDF were found for the first, and second cuts in 2017. But in third cut in 2017, the highest NDF concentration (410 g/kg $\mathrm{DM}$ ) was found in plots that had the last cut in the fall of the previous year on October 30, and the lowest NDF was found in plots that were cut on September 30 and October 15. In last (fifth) cut in 2017, the results showed that alfalfa harvested on September 15 and September 30 had an NDF concentration that was significantly lower than that in alfalfa harvested on October 15 and October 30. Min [41] observed that the cutting frequency affects the nutritive values of alfalfa, and our results agree with his. Based on the average concentrations of NDF and ADF in 2016 and 2017, NDF and ADF concentrations were higher in 2016 with four seasonal cuts than in 2017 with five seasonal cuts. Also, a significantly lower NDF concentration was found in reduced-lignin $\mathrm{Hi}$ - Gest 360 LL alfalfa and the highest NDF concentration was found in the conventional Gunner variety. The average data of 2016 show that the NDF concentration of plots that were cut in the fall on September 15 and September 30 was higher than in plots that were cut on October 15 and October 30. But in 2017, the average NDF concentration was higher in the plots that were cut on October 15 and October 30.

\section{Relative feed value}

The means and average RFV indexes of all seasonal cuttings were shown in Table 10. The highest RFV index was found in the first cut in 2016 in the low-lignin Hi - Gest 360 LL alfalfa - 170. In the second, third, and fourth cuts, the RFV index was lower compared to the rest of the seasonal cuttings but low-lignin Hi-Gest 360 LL alfalfa had the highest RFV index compared to the RFV 
Table 10. Mean RFV indexes in 2016 and 2017

\begin{tabular}{|c|c|c|c|c|c|c|c|c|c|c|c|}
\hline & & & 2016 & & & & & & & & \\
\hline & Cut 1 & Cut 2 & Cut 3 & Cut 4 & Average & Cut1 & Cut 2 & Cut 3 & Cut 4 & Cut 5 & Average \\
\hline Variety & & & & & & & & & & & \\
\hline $\mathrm{RA}$ & $150^{b}$ & $141^{b}$ & $137^{b}$ & $128^{b}$ & $139^{b}$ & $141^{b}$ & $152^{b}$ & $148^{b}$ & $144^{b}$ & $166^{b}$ & $150^{b}$ \\
\hline$A$ & $145^{\mathrm{b}}$ & $133^{c}$ & $133^{c}$ & $122^{b}$ & $133^{c}$ & $138^{\mathrm{b}}$ & $139^{c}$ & $137^{c}$ & $135^{\mathrm{c}}$ & $156^{c}$ & $141^{\mathrm{c}}$ \\
\hline LA & $170^{\mathrm{a}}$ & $159^{a}$ & $150^{a}$ & $147^{a}$ & $156^{a}$ & $170^{\mathrm{a}}$ & $172^{\mathrm{a}}$ & $171^{a}$ & $168^{a}$ & $181^{a}$ & $172^{\mathrm{a}}$ \\
\hline Last cut & & & & & & & & & & & \\
\hline 15-Sep & $151^{b}$ & $14^{b}$ & $136^{b}$ & $134^{\mathrm{a}}$ & $140^{\mathrm{b}}$ & $148^{\mathrm{a}}$ & $156^{a}$ & $152^{\mathrm{ab}}$ & $152^{\mathrm{a}}$ & $175^{\mathrm{a}}$ & $157^{a}$ \\
\hline 30-Sep & $150^{\mathrm{b}}$ & $141^{b}$ & $140^{\mathrm{ab}}$ & $135^{\mathrm{a}}$ & $141^{b}$ & $154^{\mathrm{a}}$ & $155^{\mathrm{a}}$ & $155^{\mathrm{a}}$ & $150^{\mathrm{a}}$ & $172^{\mathrm{a}}$ & $157^{a}$ \\
\hline $15-O c t$ & $158^{\mathrm{a}}$ & $148^{a}$ & $143^{\mathrm{a}}$ & $131^{a}$ & $145^{a}$ & $147^{a}$ & $157^{\mathrm{a}}$ & $152^{\mathrm{ab}}$ & $148^{\mathrm{a}}$ & $162^{b}$ & $153^{b}$ \\
\hline 30-Oct & $159^{a}$ & $147^{\mathrm{a}}$ & $141^{a}$ & $130^{a}$ & $144^{a}$ & $149^{a}$ & $152^{\mathrm{a}}$ & $149^{b}$ & $145^{\mathrm{a}}$ & $158^{b}$ & $151^{b}$ \\
\hline$p$-value & & & & & & & & & & & \\
\hline Variety & $* * *$ & $* * *$ & $* * *$ & $* * *$ & $* * *$ & $* * *$ & $* * *$ & $* * *$ & $* * *$ & $* * *$ & $* * *$ \\
\hline Last cut & $* * *$ & $* *$ & $* *$ & NS & $* * *$ & NS & NS & NS & NS & $* * *$ & $* * *$ \\
\hline Variety $\times$ Last cut & NS & NS & NS & NS & NS & NS & NS & NS & NS & NS & NS \\
\hline
\end{tabular}

${ }^{a-c}$ Different letters in the same column are significant at $\alpha$ level of either 0.05 or 0.01 .

**Significant at a level of 0.05 and ***Significant at a level of 0.01 .

RFV, relative feed value; RA, Roundup Ready Tonica alfalfa; A, Gunner conventional alfalfa; LA, low-lignin Hi-Gest 360 alfalfa; NS, not significant.

indexes of conventional Gunner alfalfa and Roundup Ready RR Tonica alfalfa. For the plots that had the last cut on October 15 and October 30 in the previous year of 2016, the first, second, and third cuts had a significantly higher $(p<0.05)$ RFV index than plots that were cut on September 15 and September 30. This might be due to slower regrowth during those three cuttings. In the fourth cut of 2016, differences in RFV due to cutting dates were not found.

In 2017 for all five cuttings, the results showed that low-lignin Hi- Gest 360 LL alfalfa had a significantly $(p<0.05)$ higher RFV index than the other alfalfa varieties. The conventional Gunner alfalfa had the lowest RFV index. In 2017, no significant differences in RFV indexes were found in the first, second, and fourth cuts among the plots that had had their last cut in the fall on four different cutting dates. In the third cut in 2017, the plots that been cut in the last cut of the previous year on September 30 had a significantly higher RFV index than the plots that been cut on October 30. In the fifth cut in 2017, which was the last cut for the season, the RFV index was highest in plots that were cut on September 15 (175) and September 30 (172), and the lowest RFV index was found in plots that were cut on October 15 (162) and October 30 (158).

Based on average data of 2016 and 2017, the significantly $(p<0.05)$ highest RFV values were found in the reduced-lignin Hi - Gest $360 \mathrm{LL}$ alfalfa and the lowest RFV was found in conventional Gunner alfalfa. In 2016, the average data showed that the plots that were cut on October 15 and October 30 had a significantly $(p<0.05)$ higher RFV value than plots that were cut on September 15 and September 30. In 2017 the average RFV was significantly $(p<0.05)$ higher in plots that were cut on September 15 and September 30 compared to the RFV values in plots that were cut on October 15 and October 30.

Rohweder et al. [32] developed the RFV index that has been used in to compare forage quality. An RFV value of 100 represents full bloom alfalfa., The higher the number, the greater is the quality of the forage. The more mature the alfalfa is at harvest, the higher the ADF and NDF concentrations will be, and the RFV index gets lower. According to Van Soest et al. [30], the RFV index does not measure nutritional content directly, but it is used for the calculation of hay quality, usually when buying or selling alfalfa hay. Based on USDA alfalfa hay classification for Kansas 
premium hay has an RFV index of 160-195. If the RFV index is 130-170, the hay is considering to be good enough for feeding during the early lactation of cows. If the RFV value is less than 140 125 , the hay could be fed to cows in late lactation. Based on 2-year average data our study showed that planting the newly developed low-lignin alfalfa could be beneficial for the producer since the forage RFV index in 2016 under four cuttings was significantly higher compared to roundup ready and conventional alfalfa variety. On the hay market, the low-lignin alfalfa variety could be considered to the premium hay grading category, and the Roundup Ready and conventional alfalfa varieties to good hay grading category. In 2017 under five cuttings the hay of low-lignin alfalfa variety was in the premium hay grading category and the roundup ready and conventional alfalfa varieties in the good hay grading category. The low-lignin alfalfa variety could provide a higher forage quality, and, at the same time, the producer can have a wide harvesting window that will not impact forage nutritive values [47].

\section{CONCLUSION}

Based on three-year data, our results suggest that producers in Kansas should cut alfalfa by September 30-October 15. The cutting during this time did not have harmful effect on DMY of alfalfa. Alfalfa yield was not affected by varieties. In general, low lignin alfalfa had higher $\mathrm{CP}$ and RFV and lower ADF and NDF than roundup ready and conventional alfalfa varieties. Also, our recommendation is to reduce the five cuttings per year to four. Future research requires to investigate the root carbohydrates in low-lignin alfalfa because it is a new variety and there is a lack of information available to the producers.

\section{REFERENCES}

1. Hancock DW, Buntin GD, Ely LO, Lacy RC, Heusner GL, Stewart RL Jr. Alfalfa management in Georgia. Athens, GA: The University of Georgia; 2015.

2. Barnhart SK. Establishing alfalfa for grazing system. In: Proceedings of the 2nd National A1falfa Grazing Conference; 1997; Omaha, NE.

3. Smith D. Cutting schedules and maintaining pure stands. Alfalfa Sci Technol. 1972;15:481-96. https://doi.org/10.2134/agronmonogr15.c22

4. Adhikari L, Lindstrom OM, Markham J, Missaoui AM. Dissecting key adaptation traits in the polyploid perennial Medicago sativa using GBS-SNP mapping. Front Plant Sci. 2018;9:934. https://doi.org/10.3389/fpls.2018.00934

5. Bélanger G, Richards JE, McQueen RE. Effects of harvesting systems on yield, persistence, and nutritive value of alfalfa. Can J Plant Sci. 1992;72:793-9. https://doi.org/10.4141/cjps92095

6. Sheaffer CC, Marten GC. Alfalfa cutting frequency and date of fall cutting. J Prod Agric. 1990;3:486-91. https://doi.org/10.2134/jpa1990.0486

7. Tesar MB, Yager JL. Fall cutting of alfalfa in the North Central USA. Agron J. 1985;77:774-8. https://doi.org/10.2134/agronj1985.00021962007700050024x

8. Brink G, Hall M, Shewmaker G, Undersander D, Martin N, Walgenbach R. Changes in alfalfa yield and nutritive value within individual harvest periods. Agron J. 2010;102:1274-82. https://doi.org/10.2134/agronj2010.0080

9. Hall MH, Smiles WS, Dickerson RA. Morphological development of alfalfa cultivars selected for higher quality. Agron J. 2000;92:1077-80. https://doi.org/10.2134/agronj2000.9261077x

10. Dhont C, Castonguay Y, Nadeau P, Bélanger G, Drapeau R, Chalifour FP. Untimely fall 
harvest affects dry matter yield and root organic reserves in field-grown alfalfa. Crop Sci. 2004;44:144-57. https://doi.org/10.2135/cropsci2004.1440

11. Davies SL, Peoples MB. Identifying potential approaches to improve the reliability of terminating a lucerne pasture before cropping: a review. Aust J Exp Agric. 2003;43:429-47. https:// doi.org/10.1071/EA02042

12. Macolino S, Scotton M, Ziliotto U, Villalobos FJ, Testi L. Response of four lucerne cultivars to two cutting frequencies. In: Proceedings of the 7th Congress European Society of Agronomy; 2002; Cordoba, Spain.

13. Giorgio B, Amedeo RDL, Ernesto T. Yield and quality of three lucerne cultivars under various harvesting schedules. In: Proceedings of the 18th General Meeting of the European Grassland Federation; 2000; Aalborg, Denmark.

14. Hoveland CS, Durham RG, Bouton JH. Weed encroachment in established alfalfa as affected by cutting frequency.J Prod Agric. 1996;9:399-402. https://doi.org/10.2134/jpa1996.0399

15. Tesar MB. Fall cutting of alfalfa under 3- and 4-cutting systems in Michigan. In: Proceedings of the 17th Central Alfalfa Improve Conference; 1981; East Lansing, MI.

16. Avice JC, Ourry A, Lemaire G, Volenec JJ, Boucaud J. Root protein and vegetative storage protein are key organic nutrients for alfalfa shoot regrowth. Crop Sci. 1997;37:1187-93. https:// doi.org/10.2135/cropsci1997.0011183X003700040027x

17. Dhont C, Castonguay Y, Nadeau P, Bélanger G, Chalifour FP. Alfalfa root nitrogen reserves and regrowth potential in response to fall harvests. Crop Sci. 2003;43:181-94. https://doi. org/10.2135/cropsci2003.1810

18. Hendershot KL, Volenec JJ. Nitrogen pools in taproots of Medicago sativa L. after defoliation. J Plant Physiol. 1993;141:129-35. https://doi.org/10.1016/S0176-1617(11)80748-0

19. Volenec JJ, Ourry A, Joern BC. A role for nitrogen reserves in forage regrowth and stress tolerance. Physiol Plant. 1996;97:185-93. https://doi.org/10.1111/j.1399-3054.1996.tb00496.x

20. Leep RH, Andresen JA, Jeranyama P. Fall dormancy and snow depth effects on winterkill of alfalfa. Agron J. 2001;93:1142-8. https://doi.org/10.2134/agronj2001.9351142x

21. McKenzie JS, McLean GE. Some factors associated with injury to alfalfa during the 1977-78 winter at Beaverlodge, Alberta. Can J Plant Sci. 1980;60:103-12. https://doi.org/10.4141/ cjps80-015

22. Macolino S, Lauriault LM, Rimi F, Ziliotto U. Phosphorus and potassium fertilizer effects on alfalfa and soil in a non-limited soil. Agron J. 2013;105:1613-8. https://doi.org/10.2134/ agronj2013.0054

23. Paquin R, Mehuys GR. Influence of soil moisture on cold tolerance of alfalfa. Can J Plant Sci. 1980;60:139-47.https://doi.org/10.4141/cjps80-019

24. Twamley BE. Variety, fertilizer, management interactions in alfalfa. Can J Plant Sci. 1960;40:130-8. https://doi.org/10.4141/cjps60-015

25. Suzuki M. Effects of stand age on agronomic, morphological and chemical characteristics of alfalfa. Can J Plant Sci. 1991;71:445-52. https://doi.org/10.4141/cjps91-061

26. Walgenbach RP. Autumn management of alfalfa affects forage yield, quality and persistence. In: Proceedings of the American Forage and Grassland Council; 1983; Eau Claire,Wi.

27. USDA. Web soil survey [Internet]. USDA-Natural Resources Conservation Service. 2017 [cited 2018 Mar 20].http://websoilsurvey.nrcs.usda.gov/

28. Mesonet K. Weather [Internet]. 2017 [cited 2017 Dec 28]. http://mesonet.k-state.edu/

29. National Alfalfa \& Forage Alliance. Alfalfa variety ratings: Winter survival, fall dormancy \& pest resistance ratings for alfalfa varieties. St. Paul, MN: National Alfalfa \& Forage Alliance; 2018. 
30. Van Soest PJ, Robertson JB, Lewis BA. Methods for dietary fiber, neutral detergent fiber, and nonstarch polysaccharides in relation to animal nutrition.J Dairy Sci. 1991;74:3583-97. https:// doi.org/10.3168/jds.S0022-0302(91)78551-2

31. Helrich K. Official methods of analysis of the association of official analytical chemists: association of official analytical chemists. 15th ed. Arlington, VA: AOAC International; 1990.

32. Rohweder DA, Barnes RF, Jorgensen N. Proposed hay grading standards based on laboratory analyses for evaluating quality. J Anim Sci. 1978;47:747-59. https://doi.org/10.2527/ jas1978.473747x

33. Institute SAS. SAS/IML 9.3. User's guide. Cary, NC; SAS Institute; 2011.

34. Bélanger G, Kunelius T, McKenzie D, Papadopoulos Y, Thomas B, McRae K, et al. Fall cutting management affects yield and persistence of alfalfa in Atlantic Canada. Can J Plant Sci. 1999;79:57-63. https://doi.org/10.4141/P98-035

35. Reynolds JH. Carbohydrate trends in alfalfa (Medicago sativa L.) roots under several forage harvest schedules. Crop Sci. 1971;11:103-6. https://doi.org/10.2135/cropsci1971.0011183X 001100010036x

36. Schoner CA. Effect of late fall harvest on alfalfa stand and yield. In: Proceedings of the 11th California Alfalfa Symposium; 1981; Berkeley, CA.

37. Sheaffler CC, Russelle MP, Hesterman OB, Stucker RE. Alfalfa response to potassium, irrigation, and harvest management. Agron J. 1986;78:464-8. https://doi.org/10.2134/agronj1986.00 $021962007800030014 \mathrm{x}$

38. Parsons JL, Davis RR. Forage production of vernal alfalfa under differential cutting and phosphorus fertilization. Agron J. 1960;52:441-3. https://doi.org/10.2134/agronj1960.0002196200 $5200080004 x$

39. Brink GE, Marten GC. Harvest management of alfalfa—nutrient yield vs. forage quality, and relationship to persistence.J Prod Agric. 1989;2:32-6. https://doi.org/10.2134/jpa1989.0032

40. Trimble MW, Barnes DK, Heichel GH, Sheafter CC. Forage yield and nitrogen partitioning responses of alfalfa to two cutting regimes and three soil nitrogen regimes. Crop Sci. 1987;27:909-14. https://doi.org/10.2135/cropsci1987.0011183X002700050016xa

41. Min D. Effects of cutting interval between harvests on dry matter yield and nutritive value in alfalfa. Am J Plant Sci. 2016;7:1226-31. https://doi.org/10.4236/ajps.2016.78118

42. Kallenbach RL, Nelson CJ, Coutts JH. Yield, quality, and persistence of grazing-and hay-type alfalfa under three harvest frequencies. Agron J. 2002;94:1094-103. https://doi.org/10.2134/ agronj2002.1094

43. Kalu BA, Fick GW. Morphological stage of development as a predictor of alfalfa herbage quality. Crop Sci. 1983;23:1167-72. https://doi.org/10.2135/cropsci1983.0011183X002300060033x

44. Ventroni LM, Volenec JJ, Cangiano CA. Fall dormancy and cutting frequency impact on alfalfa yield and yield components. Field Crops Res. 2010;119:252-9. https://doi.org/10.1016/ j.fcr.2010.07.015

45. Palmonari A, Fustini M, Canestrari G, Grilli E, Formigoni A. Influence of maturity on alfalfa hay nutritional fractions and indigestible fiber content. J Dairy Sci. 2014;97:7729-34. https:// doi.org/10.3168/jds.2014-8123

46. Rimi F, Macolino S, Leinauer B, Lauriault LM, Ziliotto U. Alfalfa yield and morphology of three fall-dormancy categories harvested at two phenological stages in a subtropical climate. Agron J. 2010;102:1578-85. https://doi.org/10.2134/agronj2010.0193

47. Grev AM, Wells MS, Samac DA, Martinson KL, Sheaffer CC. Forage accumulation and nutritive value of reduced lignin and reference alfalfa cultivars. Agron J. 2017;109:2749-61. https://doi.org/10.2134/agronj2017.04.0237 
48. Sheaffer CC, Martin NP, Lamb JFS, Cuomo GR, Jewett JG, Quering SR. Leaf and stem properties of alfalfa entries. Agron J. 2000;92:733-9. https://doi.org/10.2134/agronj2000.924733x 